\title{
GRANULAR CELL TUMOR OF CHEST WALL - A RARE OCCURENCE
}

\author{
K. P. Karumbaiah ${ }^{1}$, Preethal G², Arshiya Anjum³ ${ }^{3}$ Kuldip Dangar ${ }^{4}$, T. M. Kariappa ${ }^{5}$
}

\section{HOW TO CITE THIS ARTICLE:}

K. P. Karumbaiah, Preethal G, Arshiya Anjum, Kuldip Dangar, T. M Kariappa. "Granular Cell Tumor of Chest Wall - A Rare Occurrence". Journal of Evolution of Medical and Dental Sciences 2014; Vol. 3, Issue 10, March 10; Page: 2504-2507, DOI: $10.14260 /$ jemds/2014/2164

ABSTRACT: Granular cell tumor classically known as granular cell myoblastoma are rare benign tumors but some may be difficult to distinguish from malignant neoplasms. They have been a subject of much debate in the literature. ${ }^{1}$ Due to their usually subtle presentation; they are often misdiagnosed, with histological examination setting the correct diagnosis subsequently. ${ }^{1}$

KEYWORDS: Granular cell tumor; chest wall; histopathology.

INTRODUCTION: Granular cell tumor (GCT) or Abrikossoff's tumor is a rare neoplasm considered to be of neural origin derived from Schwann cells of the peripheral nerves. Abrikossoff was the first to describe this tumor in the literature in 1926 as a myoblastoma, since it was reported as a tumor arising from muscle in the tongue. Granular cell tumors are usually asymptomatic and present as smooth, slow-growing, solitary nodules, typically in the superficial tissues (dermis and sub cutis), along mucosal surfaces and occasionally within skeletal muscle. These tumors can arise at any part of the body but cases in the chest wall have been rarely documented in the literature. Clinically, these tumors are rare and account for approximately $0.5 \%$ of all soft tissue tumors. Here, we present a rare case of granular cell tumor of chest wall.

CASE REPORT: A 47-year-old man presented with a swelling over sternal region of one year duration. On physical examination, there was a firm, mildly tender, $3.5 \times 2.5 \mathrm{~cm}$ palpable swelling in the midline over the sternum. Overlying skin was normal and the lesion was mobile. A clinical differential diagnosis of neurofibroma and benign fibrous tumor was made. The patient underwent surgical excision of the swelling.

Grossly, it was a grey white tissue mass measuring $3.5 \times 2.5 \times 1.5 \mathrm{cms}$ with attached skin. Cut surface showed a circumscribed grey white nodule measuring $3 \times 2 \mathrm{~cm}$.

Histopathological examination showed a circumscribed tumor composed of sheets of large polyhedral cells with abundant granular cytoplasm and relatively small nuclei with mild pleomorhism [Figure. 1]. A diagnosis of granular cell tumor was made which was confirmed by subsequent immunohistochemistry study, which was positive for S-100 protein [Figure. 2].

DISCUSSION: Granular cell tumors are rare and the literature relating to them is sparse. Abrikossoff was the first to describe this tumor in the literature as a myoblastoma. Over the following 60 years the tumor was thought to be neural in origin since it was observed that tumors arising in the extremities were related to the radial and sciatic nerve trunks. Current opinion concurs with this. ${ }^{2}$

The mode of presentation of granular cell tumors is usually in the form of a painless mass and occurs most commonly between the third and fifth decades. ${ }^{2}$ 
Recently, many studies on GCTs have mainly focused on the recognition and correct preoperative diagnosis of this tumor in clinical practice, and on determining the histogenesis of this tumor by performing immunohistochemical, ultrastructural studies and cytogenetic analysis ${ }^{3}$

The benign tumor consists of large polyhedral cells arranged in sheets with abundant eosinophilic granular cytoplasm. The nuclei are relatively small and mildly pleomorphic with prominent nucleoli. Occasional mitotic figures can be present.4

The histogenesis of these tumors is still controversial but their immunohistochemical and ultrastructural features have been accepted as neural or neuroectodermal in origin because they are immunoreactive for the S-100 protein and neuron-specific enolase, and they demonstrate lysosomes on electron microscopy. They are also characterized by immunopositivity for CD68 and inhibin-alpha, but they are negative for cytokeratins. ${ }^{5}$

The differential diagnosis of GCT includes rhabdomyoma, hibernoma, oncocytoma, extragastrointestinal stromal tumor (EGIST), and the reactive changes associated with trauma and injury. The histologic characteristics and reactivity toward S-100 and CD68 distinguish GCT from rhabdomyoma, which contains glycogen and hibernoma, which contains lipid droplets. Ultrastructurally, the lack of mitochondria differentiates GCT from oncocytoma. GCTs can mimic EGIST with epithelioid cells. The negative reaction to c-kit and CD34 distinguish GCT from EGIST. The inflammatory cells and areas of necrosis in the reactive change from trauma and injury are absent in GCT. ${ }^{5}$

The distinction between a benign, atypical, and malignant GCT is challenging based upon morphology alone, as the different grades are all histologically similar. Furthermore, malignant granular cell tumors are exceedingly rare, comprising less than $1 \%$ of all granular cell tumors. The criteria proposed to distinguish between them includes: The presence of necrosis, spindle cell morphology, increased nuclear-to-cytoplasmic ratio, nuclear pleomorphism, prominent nucleoli, and increased mitotic rate $(>2 / 10$ high power fields). GCTs are classified as malignant if they display three or more of these criteria, as atypical if they display two, and as benign if they display only pleomorphism but no other criteria. ${ }^{5}$

CONCLUSION: Granular cell occurring on chest wall is quite rare. Only a few cases were presented in literature with an extended period of time before the clinical presentation of subsequent disease. Due to their subtle appearance and symptomatology as a typical subcutaneous lump, Granular cell tumors are often extemporarily misdiagnosed with histological examination setting the correct diagnosis subsequently, which carries significant clinical importance for follow-up and further management of these rare tumors.

\section{REFERENCES:}

1. GP Fragulidis, KD Chondrogiannis, PM Lykoudis, A Karakatsanis, CA Georgiou, E Vouza and A Melemeni. Subcutaneous granular cell tumor of lumbar region. J Cutan Aesthet Surg. 2011 MayAug; 4(2): 132-134.

2. Barry Rose, George S. Tamvakopoulos, Eric Yeung, Robin Pollock, John Skinner, Timothy Briggs, and Steven Cannon. Granular cell tumors: A rare entity in the musculoskeletal system. Hindawi publishing corporation Sarcoma. Volume 2009, Article ID 765927, 4 pages. 
3. Dong Baek Kang, Seok Youn Lee, Hyang Jeong Jo, Won Cheol Park. Synchronous granular cell tumors in the perianus and chest wall. J Korean Surg Soc 2011;81:70-74. DOI: 10.4174/jkss.2011.81.1.70.

4. Giovanni Francesco Marangi, Vito Toto, Igor Poccia, Pierluigi Gigliofiorito, Beniamo Brunetti and Paolo Persichetti. Multiple localization of granular cell tumor: a case report. Cases journal 2009, 2:8751.

5. Ji Young Park, M.D., Jae Joon Hwang, M.D., Song Am Lee, M.D.1, Woo Surng Lee, M.D., Yo Han Kim, M.D., Hyun Keun Chee, M.D., Wan Seop Kim, M.D. Granular cell tumor occurring in the chest wall: a case report. Korean J Thorac Cardiovasc Surg 2012;45:196-198.

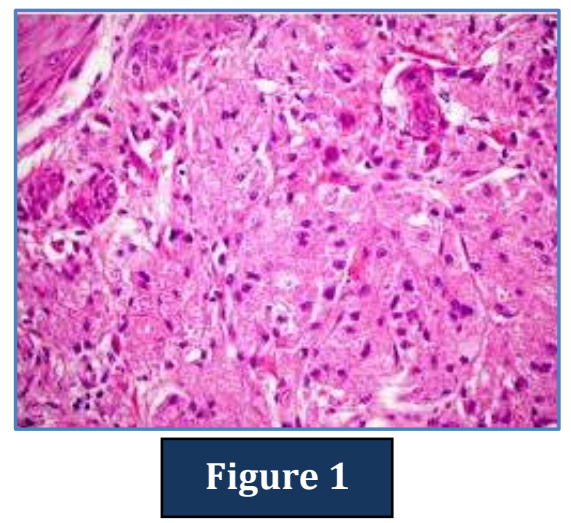

Figure 1: Sheets of large polyhedral cells having abundant granular cytoplasm and relatively small nuclei with mild pleomorphism. [Haematoxylin \& Eosin, x400]

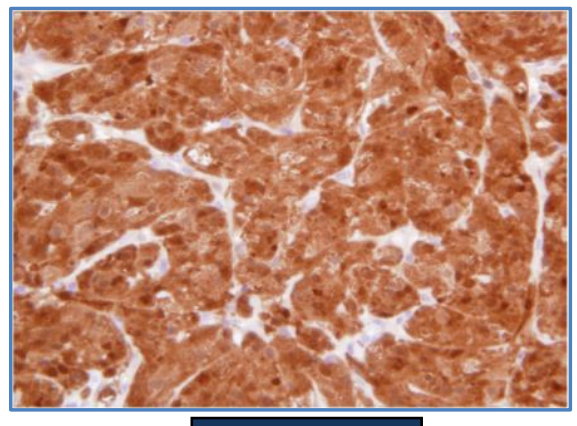

Figure 2

Figure 2: Tumor cells showing positive reaction to S-100 protein [Immunohistochemistry, $\mathrm{x} 400$ ] 


\section{AUTHORS:}

1. K. P. Karumbaiah

2. Preethal G.

3. Arshiya Anjum

4. Kuldip Dangar

5. T. M. Kariappa

\section{PARTICULARS OF CONTRIBUTORS:}

1. Associate Professor, Department of Pathology, KVG Medical College, Sullia.

2. Assistant Professor, Department of Pathology, K. S Hegde Medical College, Mangalore.

3. Post Graduate Trainee, Department of Pathology, KVG Medical College Sullia.

4. Post Graduate Trainee, Department of Pathology, KVG Medical College Sullia.
5. Professor and HOD, Department of Pathology, KVG Medical College, Sullia.

\section{NAME ADDRESS EMAIL ID OF THE CORRESPONDING AUTHOR:}

Dr. K. P Karumbaiah, Associate Professor, Department of Pathology, KVGMC, Sullia, D. K, Karnataka.

E-mail: karumbaiahkp@yahoo.com

Date of Submission: 09/02/2014. Date of Peer Review: 10/02/2014.

Date of Acceptance: 19/02/2014.

Date of Publishing: 04/03/2014. 